\title{
German Greens attenuate their genetic resistance
}

The German Green party is slowly changing its attitude towards gene technology. According to its leading spokesman on science and technology in the Bundestag, the federal parliament, the old, all-encompassing, stridently negative attitudes are mellowing. Manuel Kieper says most party members have an open mind toward the use of gene technology in medicine and research. "I can see that gene technology will bring a certain advantage in diagnostics and therapy," he says. Attitudes toward the agricultural uses of biotechnology, however, have changed little.

Kieper represents a growing voice of moderation in the party. In 1994, a third of the participants of the Greens' Federal Delegates' Conference in Mannheim voted to accept some aspects of gene technology in medicine. Kieper thinks that this would now be the majority view among both delegates and the grassroots party members. The current softer opinion is also reflected in the fact that, although the Greens reaffirmed their opposition to gene technology in October 1997, they are no longer demanding a halt to research as they have done in the past.

The elections in Germany at the end of this year will certainly focus the Green mind. A coalition with the left-of-center Social Democrats-the most likely path to power for the Greens-would be facilitated if the two parties could agree on as broad a range of issues as possible. Kieper denies, however, that this kind of short-term pragmatism is behind the present stance on gene technology. He says he has been arguing for 11 years for a more realistic attitude toward gene technology. "It is important to have a realistic approach to technology and not to give promises that cannot be kept."

Nevertheless, the impending election may be serving to quiet the passionate resistance to gene technology among the Fundis (the Green party fundamentalists). While the Green party from Baden Württemberg in southern Germany has signed up with Kieper's Realos (realist) moderates, Green parties elsewhere have kept silent. This silence certainly does not reflect the absence of anti-gene technology sentiments. Heike Moldenhauer, a Fundi and spokesperson for the Working Group on Gene Technology and Reproduction Technology of the Green party wrote in a recent article, "As in no other political field, the attitude towards gene technology will show how 'green' the party really is."

Ellen Perrenboom is a freelance writer working in Cologne, Germany.
The German Green party may have to become a broad church on medical issues, encompassing diverse views. Moldenhauer and the fundamentalists are strictly against any use of gene technology. Genetic testing, for

\section{"As in no other political field, the attitude toward gene technology will show how 'green' the party really is."}

instance, one of the least controversial uses of gene technology, is in her view, "eugenics from the start." Kieper concurs somewhat with the party line that genetic testing might lead to increased "eugenic" abortion, but he argues that social and ethical controls, rather than bans on gene technology itself, are the best way to counter the problem. Kieper even believes that the use of "knockout" mice for research can be justified, although he admits this is not a view shared by many of his colleagues.
Where the Greens remain united is in their strong opposition to plant-gene technology. "We see no advantage for the consumer," says Kieper. "Developing resistance in plants to diseases and pests should be put on a broader basis using traditional plant breeding. A plant can be changed easily, but the consequences [to the environment] of doing so are very hard to predict." However, he does concede that genetic techniques such as marker-based selection during plant breeding and the diagnosis of plant diseases can be useful. Ernst Raschke of the Hoechst/Schering agrichemical and biotechnology joint venture, AgrEvo (Frankfurt and Berlin), welcomes this concession and believes that it may have an important impact on the thinking of ordinary Germans: "It is a good sign that the Greens are becoming more open minded. ... The Green party has a major influence on our environmental organizations [and] so strongly influence public opinion of biotechnology." However, he thinks that by shunning the use of genetically modified plants, the Greens are rejecting potential solutions for other environmental issues.

Ellen Perrenboom

\section{Thrombolytics still ahead, despite study that favors angioplasty}

Companies producing tissue plasminogen activator (tPA), streptokinase, and other next-generation thrombolytic enzyme drugs for treating heart attacks may have little to worry about even though a recent article published in The Journal of the American Medical Association (278:2093-2098, 1997) suggests that angioplasty is "more cost-effective than thrombolysis". On the basis of combined results from 10 separate trials, the authors reach this conclusion albeit with a caveat that "estimates of efficacy [have] varied considerably from study to study."

The collected results from the 10 trials indicate that patient survival to 30 days after angioplasty is better than for those given streptokinase or tPA $(4.4 \%$ death rate compared with $6.5 \%$, respectively). The results also show that rates of death and/or nonfatal second heart attack are lower for angioplasty patients $(7.2 \%$ compared with $11.9 \%$ for thrombolytic therapy) and also that angioplasty patients have a lower rate of stroke than those given thrombolytics, particularly tPA.

However, many inside and outside the medical profession, including Salim Yusuf and Janice Pogue, the authors of an accompanying JAMA editorial, believe the study is of questionable value. Yusuf and Pogue suggest that there are potential biases in the studies, such as the relatively short follow-up period (30 days) and the fact that angioplasty patients are discharged from the hospital sooner than those receiving thrombolysis. For instance, the 1-month results of the Global Use of Strategies to Open Occluded Arteries in Acute Coronary Syndrome (GUSTO) IIb trial, a longer-term heartattack study published in June 1997 (N. Eng. J. Med., 336:1621-1625, 1997), showed similar results in the rates of death/new heart attack/stroke $(9.6 \%$ vs. $13.7 \%$, following treatment with angioplasty or thrombolytic drugs, respectively), but after 6 months, there was no statistical difference between the treatments.

Yusuf and Pogue also note that the analysis was conducted on a relatively small number of patients (1316) and that the data were not consistent across a range of outcomes. Therefore, they suggest that its conclusion may not be robust, and characterize angioplasty as a reasonable-but not a pre- 